\title{
MATHEMATICAL MODELING OF FLOOD MANAGEMENT SYSTEM IN THE CITY OF GDAŃSK, ORUŃSKI STREAM CASE STUDY
}

\author{
Tomasz Kolerski, Dominika Kalinowska \\ Department of Civil and Environmental Engineering, Gdańsk University of Technology, ul. Gabriela Narutowicza 11/12, \\ 80-233 Gdańsk
}

\begin{abstract}
Aim of the study

This study analyses the efficiency of flood protection in a small urban catchment, based on a system of small reservoirs.

\section{Material and methods}

To assess the flood routing and surge reduction, a mathematical model of the river catchment was implemented. This was a lumped hydrological model, based on the SCS-CN method. Channel routing was performed, using kinematic wave equation. The sub-catchments have been determined based on the topographic maps and rain sewage systems. In the paper, the hydrological model of the water system of Potok Oruński (Oruński Stream) is presented with particular focus on the new and renovated retention structures. Hydrological modelling system of HEC HMS was used to simulate the catchment's response to precipitation. Thanks to the recently established monitoring system of the Oruński Stream, it was possible to calibrate and validate the model. Single rain episode from April 2018 was used to perform model calibration, proving its high compatibility. The calibrated model was then used to reproduce the flood surge of July 2001, using historical catchment data. The peak discharge demonstrated a need for additional retention in the studied catchment. Theoretical scenarios were also modelled. The precipitation volume was calculated based on the IFS. As a worst-case scenario, the rain producing the most intense surface runoff was included. In all simulations, historical conditions as well the current state (2018) and projected further urbanisation of the catchment were taken into consideration.
\end{abstract}

\section{Results and conclusions}

Results of the study have shown reduction of the historical flood surge from July 2001 by nearly $60 \%$ when all existing flood protection systems were used.

Keywords: mathematical modelling, HEC-HMS, Oruński Stream

\section{INTRODUCTION}

Mathematical modelling is often used to analyse hydrological phenomena (Gąsiorowski and Szymkiewicz, 2007; Gąsiorowski and Artichowicz, 2016). Most often, such analyses are performed in the case of uncontrolled catchments, when there is no other possibility to calculate design flow and control flow or other characteristic flows (Wałęa, 2013; Egiazarova et al., 2017). The use of precipitation-runoff models is burdened with the risk of erroneous estimation of catchment parameters or incorrect selection of the model for the analysed phenomenon (Szydłowski and Mikos-Studnicka, 2016). In the case of urban catchments, erroneous estimation of design flows and control flows may lead to serious infrastructure losses and

区e-mail: tomasz.kolerski@pg.edu.pl 
to the damage or destruction of regulatory structures (Szydłowski and Zima, 2013). The purpose of this work is to confirm the correctness of the adopted calculation procedure for computing the runoff from an uncontrolled catchment in the urbanized area.

In order to verify the reliability of the results obtained from hydrological models, it is necessary to calibrate them using real data. Unfortunately, in most cases, the use of precipitation-runoff models results from the fact that the actual measurement data is missing, and therefore the results can only be treated as estimates, not supported by real-life observations. The only verification may be the so-called expert knowledge and experience of people managing the given catchment. The case of Gdańsk is atypical, because the newly created monitoring network for water levels and precipitation volumes made it possible to calibrate a previously constructed mathematical model. In this situation, the evident aspects of the local catchment of the city of Gdańsk notwithstanding, an optimal procedure can be developed to adapt in other similar real-life cases or scenarios.

The calibrated hydrological model can be used to determine the parameters of flood waves in uncontrolled catchments. This applies to both the hypotheticals, and the verification of wave parameters from previous years, where we often used estimated data. In order to confirm the hypothesis, a hydrological model was adapted to a small urban catchment located in Gdańsk, where a monitoring network has been operating since November 2017. Having a calibrated mathematical model, it is possible to demonstrate the effectiveness of the flood system's operation, and to find its weak points, for example places where it is necessary to apply additional technical solutions in order to increase the catchment's retention capacity. As shown by the results obtained from the mathematical model, it is also possible to precisely determine the actual operation of regulatory devices. An example is the diversion structure, in which the water distribution was only an estimate.

The location of the city of Gdańsk significantly impacts the risk of flooding, the origin of which is three-fold: storm surges, flood surges on the Vistula river (especially during the ice-breaking period (Kolerski, 2014)), and floods on the streams flowing from the Gdańsk plateau. In recent years, the most fre- quent cause of flood freshets in the area of the city of Gdańsk has been heavy rainfall, causing the surges in small streams flowing through the city. These events typically take place in the summer months, whereas the last three floods occurred in July 2001, 2016 and 2017. The first of the aforementioned events, the flood of July 2001, which caused significant damage to the urban infrastructure, was a clear signal for the city authorities that it is necessary to undertake the task of developing and implementing the flood protection system (Majewski et al., 2006; Szydłowski et al., 2015). The works encompassed both the water distribution system and increasing the retention capacity of urbanisation-affected areas, focusing in particular on the Radunia Canal catchment. A significant example is the catchment of Potok Oruński (Oruński Stream), the largest stream that feeds the Radunia Canal. As a result of work on the flood protection of the Gdańsk Water Junction, 6 retention reservoirs were built in the Potok Oruński catchment, with a total capacity of a flood storage amounting to over 400 thousand $\mathrm{m}^{3}$. The launch of the flood protection system of the Radunia Canal catchment, although still not fully completed, has contributed to a significant reduction of the damage observed during the freshets in 2016 and 2017. It should also be noted that the depth of rainfall in 2016 was almost 40\% higher than in 2001 (Szpakowski, Szydłowski, 2018), yet there was almost no damage to the region of Orunia Dolna. This confirms that the flood protection system in this area of the city had been designed correctly. Currently, work is underway on the completion of another reservoir (Z3), whose main objective is to complement the flood protection system, especially in the context of further urbanization of the catchment area, consistent with the municipal spatial development plans.

In spite of increasing expenditures on the flood protection system of the city of Gdańsk, occurring as a result of heavy rainfall, losses caused by the flood may call into question the validity of the adopted technical methods. The main purpose of this work is to show the efficiency of a flood protection system that is based on retention reservoirs. The implementation of the stated objective was carried out using a calibrated hydrological model. The conclusions obtained are of universal nature and they are not limited to the catchment analysed in the present work. 


\section{MATHEMATICAL MODEL}

When designing hydrotechnical facilities, which include retention reservoirs, it is necessary to adopt basic (design) and emergency (control) load systems in accordance with the applicable provisions of the Act of 20 April 2007, while taking into account the regulations of the Water Law Act. Because there have been no flow observations conducted on the Oruński Stream, then in order to establish design flow and control flow for the reservoir No. 3, a precipitation-runoff model was required. In this case, precipitation was assumed as input data with a probability of exceedance of $1 \%$ (design precipitation) and $0.5 \%$ (control precipitation). The constructed mathematical model was based on the SCS - UH (Soil Conservation Service - Unit Hydrogram) method, in which precipitation time distribution was adopted in accordance with the guidelines presented by Maniak (1988). As it was not possible to state unambiguously, which precipitation would generate the most unfavourable inflow to the designed reservoir, it was necessary to check all the durations of potential precipitation with both design and control probability of exceedance. The numerical analysis took into account rainfall episodes with the duration of $30,60,90,120,150,180,210,360,480$, $720,960,1200$, and 1440 minutes. The worst-case scenario (causing the largest runoff hydrogram) was adopted as the design precipitation. Due to the number of events required for the analysed case, the HECHMS model package was used for numerical analysis of the catchment. A group of models from the HEC family is contained in the software package developed by the US Engineers Corps, used to solve engineering problems related to water flow hydraulics (HEC-RAS) and - broadly understood - hydrological calculations including surface runoff computations (HEC-HMS). A number of applications of the HEC package have demonstrated its effectiveness and high efficiency in solving many engineering problems (Olechnowicz, Weinerowska-Bords 2014, Dysarz 2018). The amount of precipitation was calculated using the IMGW method with appropriately selected coefficients recommended for the northern part of Poland (Bogdanowicz, Stahy, 1998).

The Oruński Stream is a watercourse with the length of about $7.5 \mathrm{~km}$, having its source in Rębów (on the ordinate about $125 \mathrm{~m}$ above sea level). It is the largest inflow of the Radunia Canal, draining the water from the plateau towards the east. It flows under the beltway of the Tri-City, and then it connects with the Szadulski Stream. While flowing through the districts of Gdańsk, it connects with the Kozacki Stream flowing from the west, and with Kowalski Stream. The stream has a poorly developed river network, which is also asymmetrical. The stream flows into the Radunia Canal at an altitude of $10 \mathrm{~m}$ a.s.l. in the vicinity of Raduńska street. At present, a large share of the water is supplied to the stream by a rain drainage system in the form of two main collectors (see: Figure 1). According to the work by Pietruszyński and Cieśliński (2016), the majority of the river catchment actively participates in feeding the watercourses, while only a little over $10 \%$ remains endorheic.

The implementation of the mathematical model of the Potok Oruński catchment basically required designation of the catchment's and the sub-catchments' boundaries. This operation was performed for the current (existing) and historical conditions from 2001, based on topographic maps and basic maps, on which rain water drainage systems were plotted. The catchment areas of both analysed cases, i.e. the historical situation of July 2001 and the current situation, differed from each other. This is due to the progressing urbanization of the area, and the inclusion of newly constructed districts - originally located outside the boundary of the catchment - and connecting them to the main rainwater collectors. It was assumed that in the event of a situation compliant with the zoning plan, the catchment area would not change further. The current division into catchments and sub-catchments for the 2018 situation is shown in Figure 1. Ultimately, the mathematical model consisted of 30 catchments, with a total area of $15.1 \mathrm{~km}^{2}$.

Classification of soils in the catchment area of the stream was elaborated on the basis of soil maps available in the cartographic resources of the Regional Office. The division into individual soil types was made in accordance with the guidelines of the SCS method, which distinguishes soil classes based on the filtration rate. That division is presented in Figure 2, where it is easy to see the predominance of type $\mathrm{B}$ and $\mathrm{C}$ soils, and a small amount of D type soils with the lowest filtration capacity. 


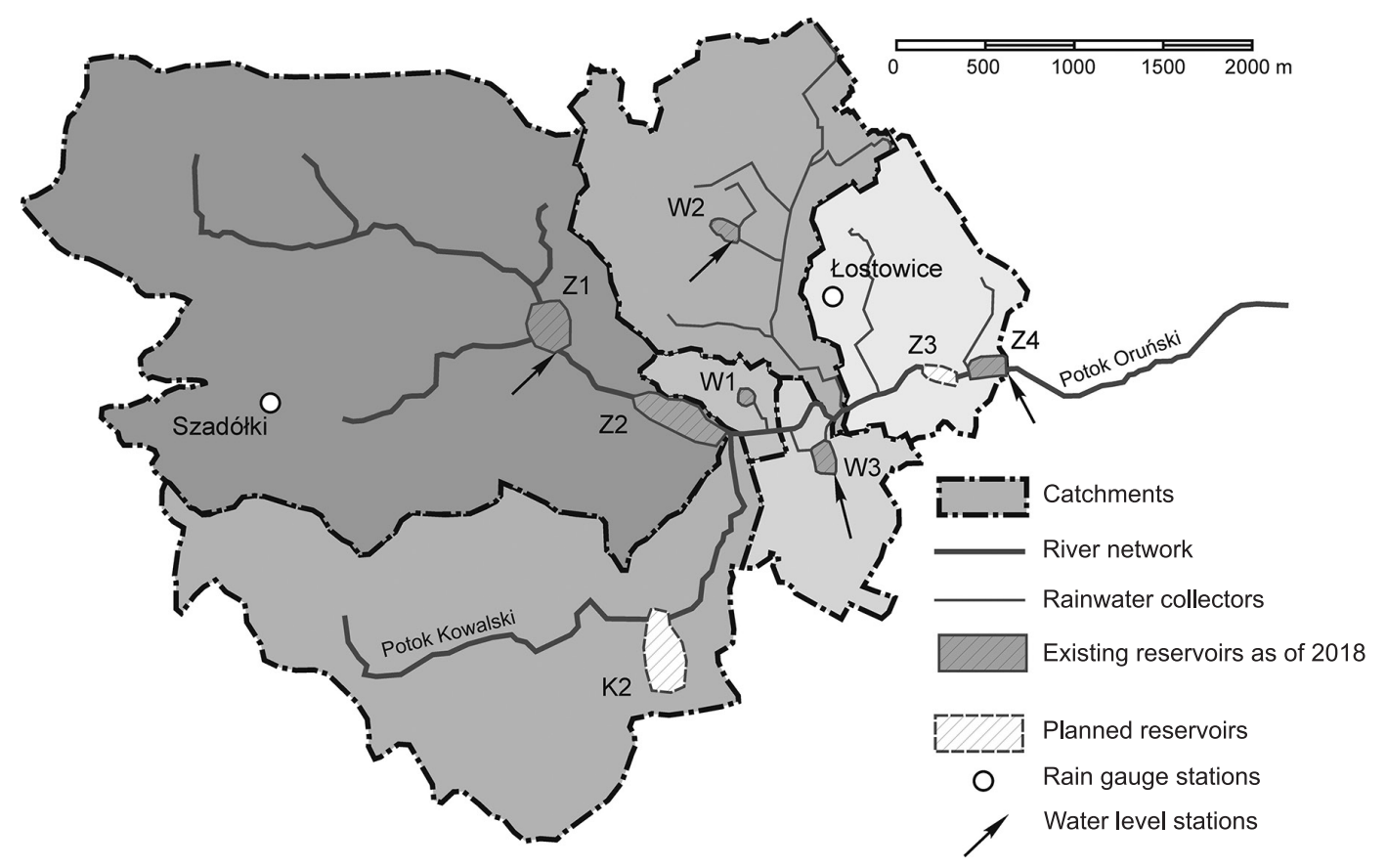

Fig. 1. Catchment of the Oruński Stream with closing cross-section of Augustowska dam (Z4) with selection of main sub-basins and flood retention reservoirs (as for 2018); arrows indicate water level stations used to model calibration

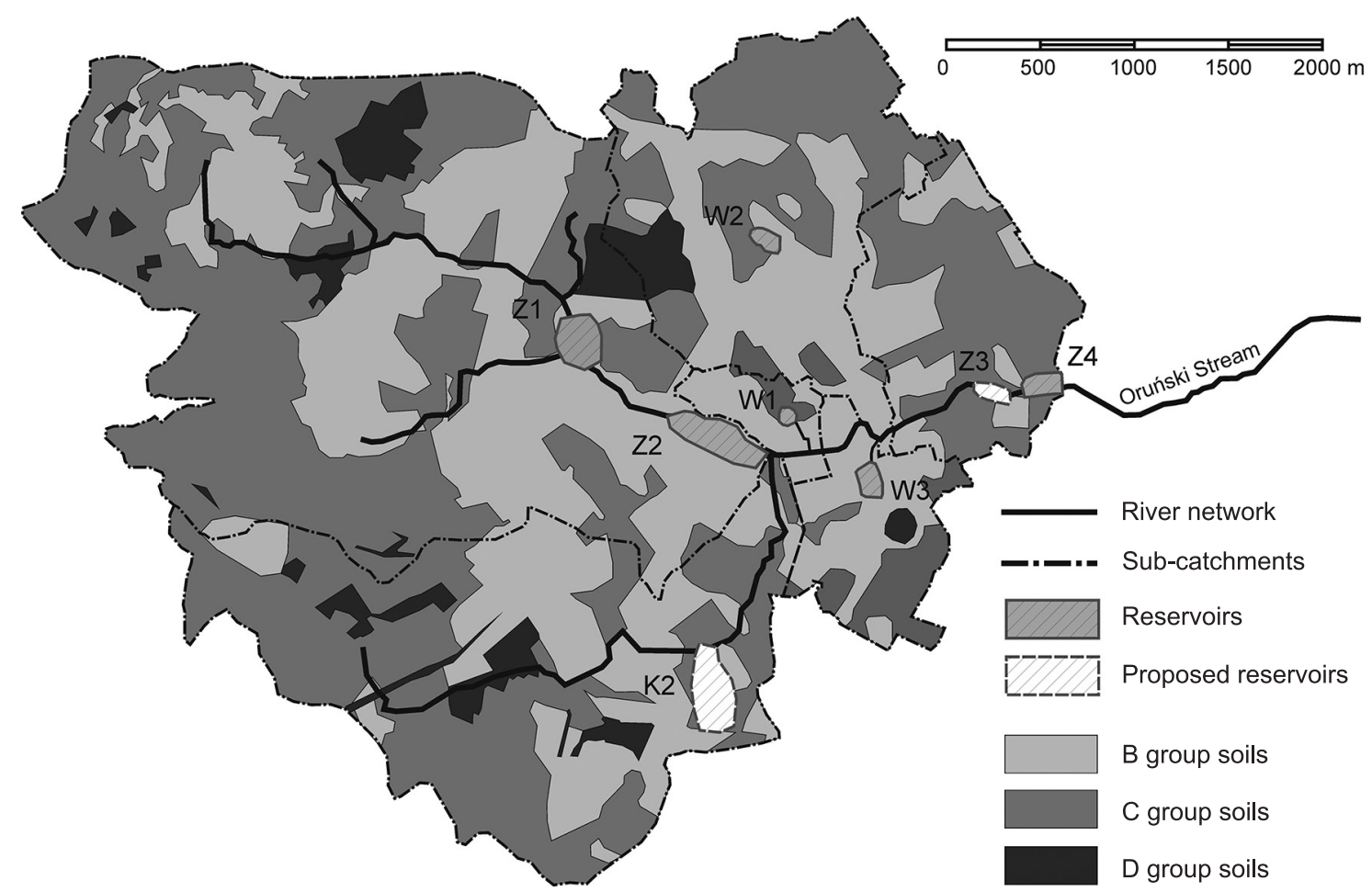

Fig. 2. Soil type map of the Oruński Stream basin; soil groups according to the SCS method 
The next stage of the work was the classification of land use in the catchment area, in accordance with the land development status in 2001, the existing development status (2018), and also taking into account prospective urbanization in accordance with local spatial development (zoning) plans. In the future plans for the development of the southern districts of the city, where urbanization will result in losses to the natu- ral retention capacity of the catchment, contemporary methods of capturing rainwater are envisaged using techniques termed as "spongecity". The goal of this is to maintain or increase the current retention capacity of the areas, which are undergoing intensive urbanization. Examples of land use in the direct catchment of reservoir No. 4 (Augustowska) for three types of builtup areas are shown in Figure 3.
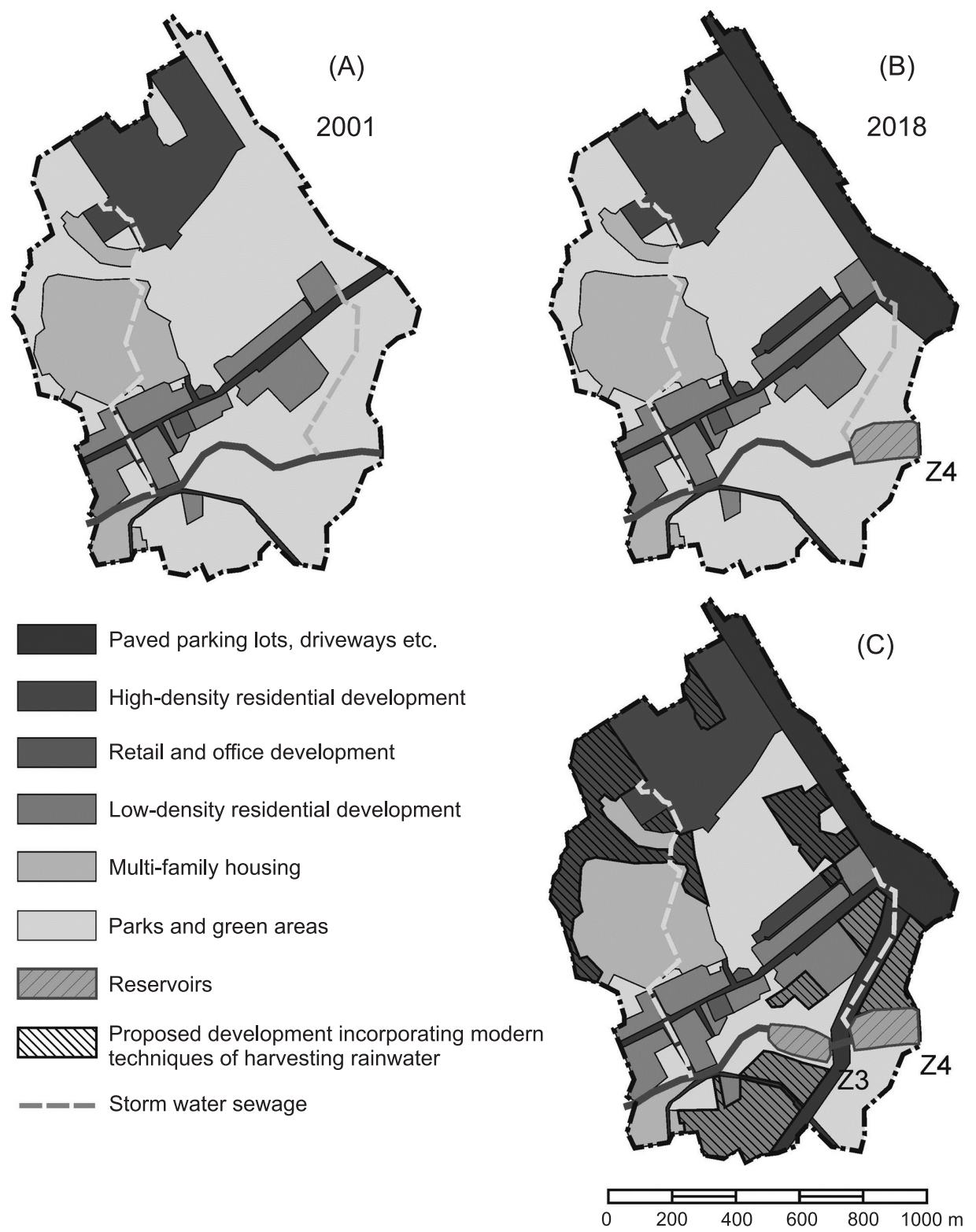

Fig. 3. Land use of the direct basin of Z3 and Z4 reservoirs showing: historical - year 2001 (A), current - year 2018 (B) and proposed (C) conditions 
The time of concentration (lag time) was determined using methods, the first of which is referred to as the segment method (McCuen et al. 2002, Weinerowska, 2010). In the segment method, the time period in which a drop of water travels from the most hydraulically disadvantaged location within the catchment to reach the cross-section which is closing the catchment, is divided into three components:

$$
t_{c}=t_{s}+t_{s c}+t_{p}
$$

where:

$t_{s}$ - "film" runoff of rainwater on the slope, which is formed on smooth surfaces, not exceeding a depth of $5 \mathrm{~cm}$ on a section not greater than $25 \mathrm{~m}$;

$t_{s c}-$ concentrated shallow water flow - to simplify, the time when water from the slope runoff (when that occurs) reaches the channel;

$t_{p}$ - flow time in the channel, calculated using the known hydraulic formulas; in this case, the kinematic wave routing method was used.

As the second method, we applied the equation used to calculate the concentration time according to the SCS formula, which depends on the gradient of the terrain, and on the potential catchment retention capacity (Mays, 2005; Heathcote, 2009). The choice of this method was informed by the fact that the length of concentration time in the analysed catchment was chiefly impacted by the time in which the water reached the river network and storm water drainage. For this reason, in our study we have tested the formula, which used the gradients of the terrain and the $\mathrm{CN}$ coefficients, describing the land use and soil types occurring in the catchment.

$$
t_{c}=\frac{L^{0.8}\left(25.4\left(\frac{1000}{C N}-10\right)+1\right)^{0.7}}{1900 \sqrt{S}}
$$

where:

$L$ - length of the runoff route;

$S$ - gradient of the terrain.

The calculations made using the HEC-HMS mathematical model have shown that the largest water flow on most of the river network and storm water drainage network occurs during a precipitation that lasts $90 \mathrm{~min}$ utes. This situation also led to the largest filling of the designed retention reservoir No. 3, which is located in the lower part of the stream's catchment. This is due to very large differences in heights (gradients of up to $10 \%$ ) in the terrain, and the low roughness of the terrain, caused by the urbanization. The calculations were made for both methods of determining the time of concentration. The volume curve of the designed reservoir and the capacity curve of the spillway structure were presented in the work by Kolerski, Szawurska (2017).

\section{CALIBRATION OF THE MODEL}

Calibration of hydrological precipitation-runoff models is not a frequent situation, because the implementation of such a model is generally the result of the lack of data on the water levels and flow rates in the rivers covered by the analysis. In the discussed case of the Potok Oruński catchment, the monitoring system was installed in November 2017, which made it possible to analyse how the catchment operates during precipitation. The short time of the monitoring system operation, which additionally covered the winter period and dry spring, was not conducive to the comprehensive calibration. For this reason, the calibration was limited only to the analysis of one rainfall episode, with greatest intensity occurring in the night hours from March 31 to April 1, 2018. During that time, the precipitation over Gdańsk was in the range from 10.9 (Przegalina) to $27 \mathrm{~mm}$ (in the station within the premises of the PAN Polish Academy of Science Institute of Hydraulic Engineering). The spatial distribution of the precipitation throughout the administrative area of Gdańsk, computed using the Shepard method, is shown in Figure 4. Additionally, the time distribution of the precipitation measured at the Lostowice station is shown (see: Fig. 4a). Unfortunately, one of the key locations for the calibrated catchment, namely the Szadółki station, was excluded from operation for technical reasons between March 21 and April 4, and it was not possible to include it in the calibration. Rainfall data was introduced to the model with a one-hour resolution. For calibration, 4 out of 13 water gauging stations installed on Potok Oruński were used. The observed water conditions were compared in the reservoirs at 


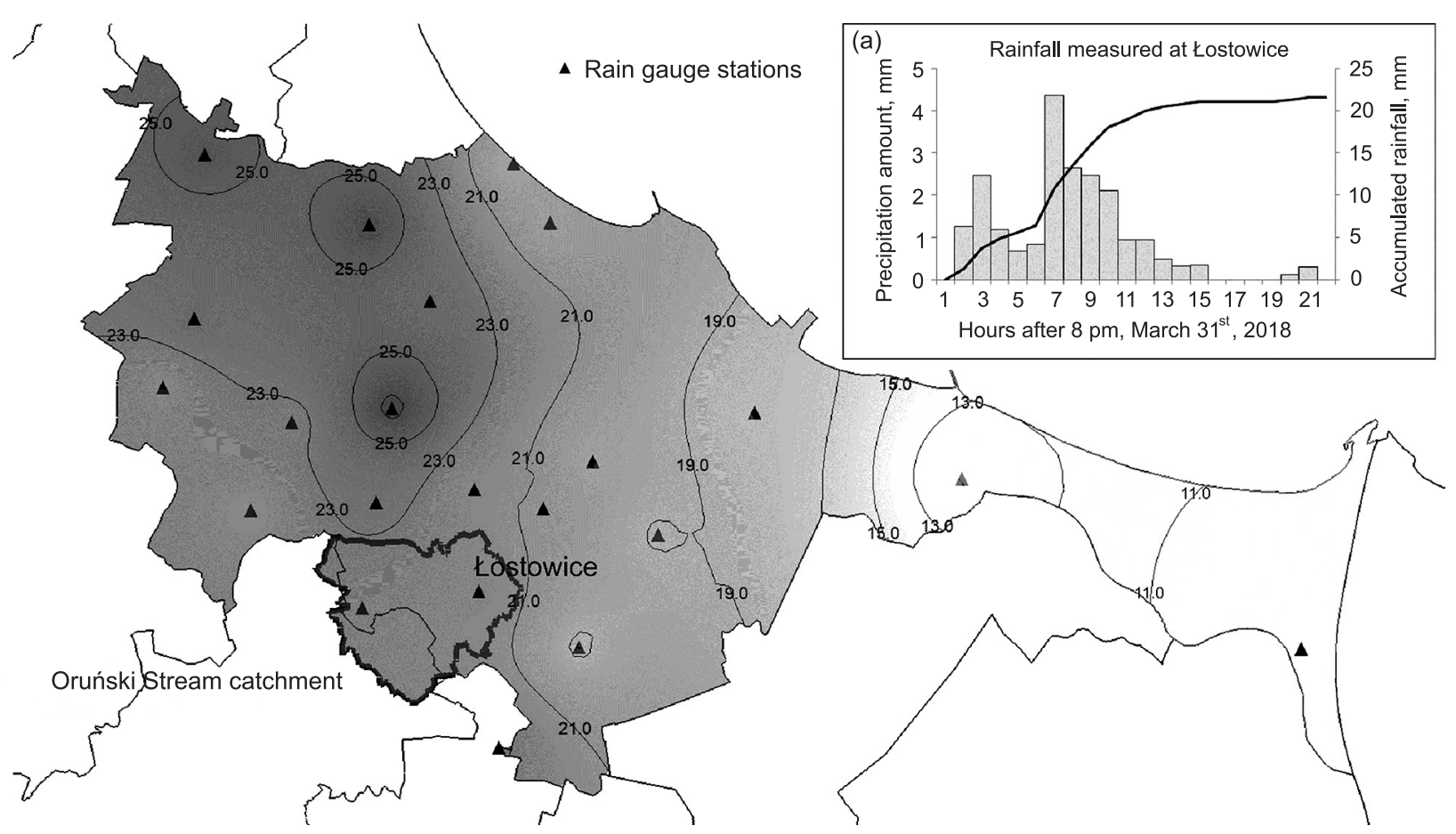

Fig. 4. Izohyetal map of one day rainfall distribution over the City of Gdansk between March $31^{\text {st }}$ to April $1^{\text {st }}, 2018$, Rainfall hyetograph and cumulative rainfall hyetograph measured at Łostowice (a)

Świętokrzyska 1 (Z1) and Wielkopolska (W3) as well as the closing reservoir at Augustowska (Z4). Locations of all the stations are shown in Figure 1.

The calibration results we have obtained indicate a high compliance with the observations both in terms of the duration of the freshet and the ordinates of the water table. In Figure 5, the graphs of the position of the measured water status on the three reservoirs were compared with the values calculated using the HECHMS model for the current existing conditions, using two methods of calculating the concentration time. High compliance of the obtained results of water levels in the reservoirs with the observed values indicates that calculation of hydrological losses was correct in the determination of effective precipitation. Furthermore, the calculated culmination time consistent with the culmination recorded during the freshet confirms the correct determination of concentration times in sub-catchments.

In order to determine the degree of compliance of the modelled results with the observations, a comparative analysis was carried out, specifying the variance $\sigma^{2}$ and the standard deviation from the actual value of $\sigma$ (Węglarczyk, 2010):

$$
\begin{gathered}
\sigma^{2}=\frac{1}{n} \sum_{i=1}^{n}\left(x_{i}-x_{\text {actual }}\right)^{2} \\
\sigma=\sqrt{\sigma^{2}}=\sqrt{\frac{1}{n}} \sum_{i=1}^{n}\left(x_{i}-x_{\text {actual }}\right)^{2}
\end{gathered}
$$

The results of the calculations for the three reservoirs are presented in the Table, including the sum of deviations from the calculated value of $\Sigma \Delta x$, the mean deviation $\Delta x_{\hat{s r}}$, the maximum and the minimum deviation $\Sigma x_{\max }$ and $\Sigma x_{\min }$, as well as variance $\sigma^{2}$ and standard deviation $\sigma$.

Based on the report presented in Table 1, it can be easily observed that surface runoff calculations both using the SCS method and using the segment method - underrepresent the surface runoff flow from the sub-catchment. Better mapping was obtained for the segment method, which allowed for a precise es- 

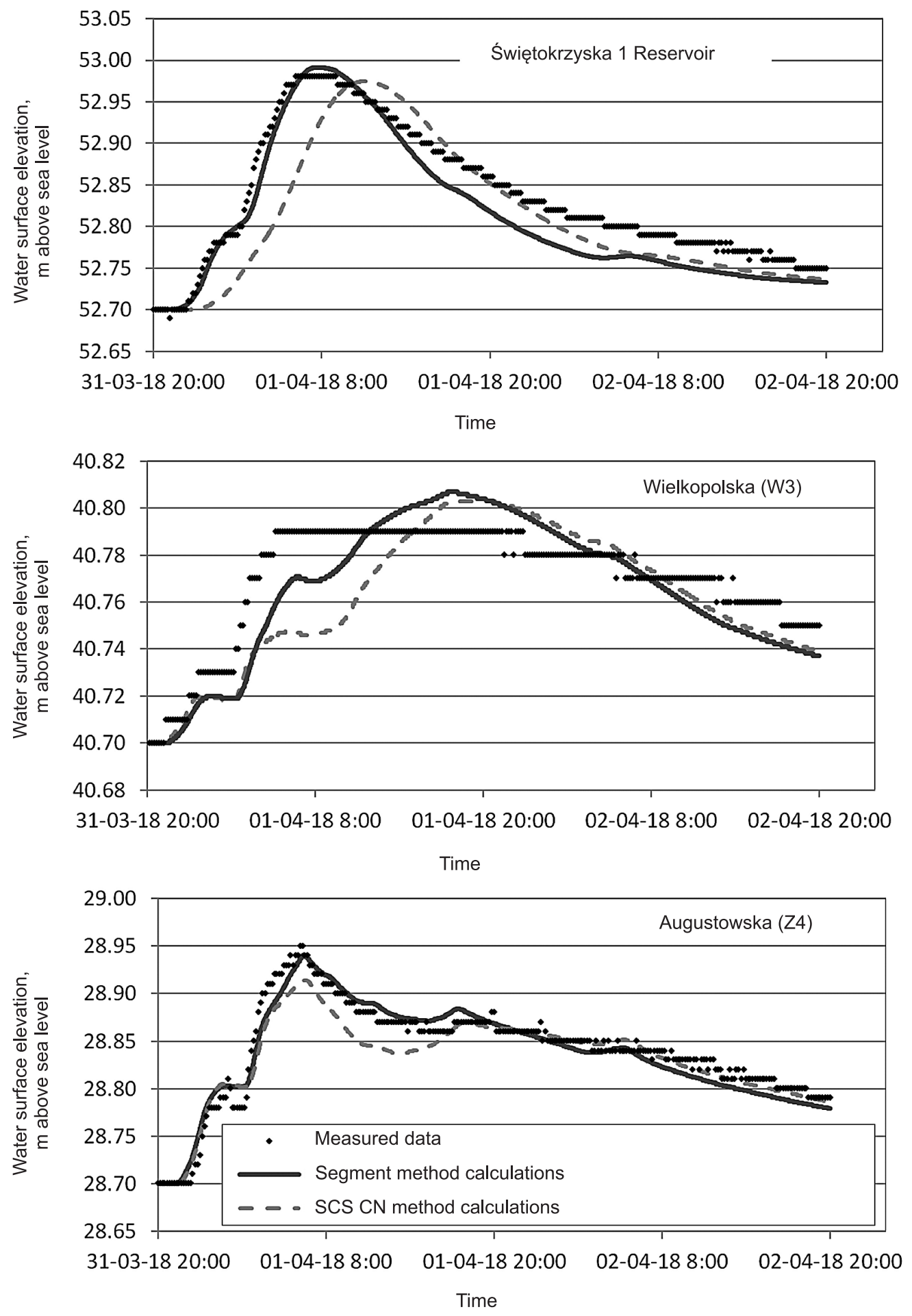

Fig. 5. Observed (dots) verses calculated (solid line) water surface elevation in reservoirs Świętokrzyska 1, Wielkopolska and Augustowska 
timation of the time of the culmination of the flow. Modelling that accommodated the concentration time computed according to the SCS methods resulted in calculations that delayed the culmination time by more than 2 hours in relation to the actual time (for Świętokrzyska 1 reservoir). Despite these differences, the results obtained are close to the actual figures. The mean standard deviation for the SCS method is 0.0268 ; and for the segment method, it is 0.0183 . The maximum deviations are 0.044 for the SCS method, and 0.048 for the segment method.

Table 1. Statistical analysis of the measured and computed water levels in the reservoirs of the Oruński Stream

\begin{tabular}{ccccccc}
\hline & \multicolumn{2}{c}{$\begin{array}{c}\text { Augustowska } \\
\text { reservoir }\end{array}$} & \multicolumn{2}{c}{$\begin{array}{c}\text { Wielkopolska } \\
\text { reservoir }\end{array}$} & \multicolumn{2}{c}{$\begin{array}{c}\text { Świettokrzyska1 } \\
\text { reservoir }\end{array}$} \\
\cline { 2 - 7 } & \multicolumn{3}{c}{ Lag time, according to equation no.: } \\
\cline { 2 - 7 } & $(2)$ & $(1)$ & $(2)$ & $(1)$ & $(2)$ & $(1)$ \\
\hline$\Sigma \Delta x$ & -2.297 & -0.634 & -2.115 & -1.248 & -6.909 & -6.464 \\
\hline$\Sigma|\Delta x|$ & 3.649 & 3.090 & 4.153 & 3.370 & 9.035 & 7.063 \\
\hline$\Delta x_{\text {ś }}$ & -0.008 & -0.002 & -0.007 & -0.004 & -0.024 & -0.022 \\
\hline$|\Delta x|_{\text {ś }}$ & 0.012 & 0.011 & 0.014 & 0.012 & 0.031 & 0.024 \\
\hline$\Delta x_{\min }$ & -0.042 & -0.031 & -0.044 & -0.037 & -0.136 & -0.048 \\
\hline$\Delta \mathbf{x}_{\max }$ & 0.024 & 0.029 & 0.022 & 0.021 & 0.037 & 0.015 \\
\hline$\sigma^{2}$ & 0.0003 & 0.0002 & 0.0004 & 0.0002 & 0.0019 & 0.0008 \\
\hline$\sigma$ & 0.0173 & 0.0128 & 0.0189 & 0.0139 & 0.0441 & 0.0282 \\
\hline
\end{tabular}

$\Delta x>0$ means overestimation of the values

$\Delta x<0$ means underestimation of the values

$\Delta x=0$ means correct estimation of the values

An interesting element of the Oruński Stream system is the diversion structure located downstream of the Świętokrzyska 2 reservoir (Z2). Its task is to divert some of the water from the Oruński Stream to the Wielkopolska (W3) reservoir. Despite the fact that the diversion structure has been operational in this location for many years, the proportions of flow directed to the reservoir and downstream have not been determined as yet. Using the monitoring data, the separation structure was calibrated, stating that the best calculation results are obtained for the following division of the flow: $80 \%$ to Wielkopolska reservoir, and the remaining $20 \%$ downstream. In the diagram of water levels in the Wielkopolska reservoir, we can observe that in the initial phase of flooding, the inflow is slightly underestimated, whereas the recorded peak is slightly overestimated $(2.5 \mathrm{~cm})$. The cause for this can lie in the fact that the outflow from the diversion structure downstream could have been blocked in the first phase of the flood. After the arrival of a larger-volume flow, perhaps the material blocking the outflow was washed away, which caused the redirection of more water down the stream. In the mathematical model, the time-varying distribution of water in the separating structure was not applied.

\section{FLOW CALCULATIONS DURING THE 9 JULY 2001 FLOOD}

The flood of July 2001 caused serious damage to urban infrastructure due to a significant inflow of rainwater to the Radunia Canal, exceeding its capacity. This resulted in breaching the embankments of the canal in 4 places and the flooding of urban areas located on the left bank, which are mostly depressed below the surrounding area. The volume of water flow in the Radunia channel is not known due to the lack of measurement infrastructure. Some estimated calculations were made using the geomorphological hydrogram method, however in this case simplified river network and rainwater drainage diagrams were used (Kolerski, Kowalik, 2014).

Using the calibrated mathematical model of the part of the Oruński Stream, an attempt was made to determine the water flow in the closing section located at the level of the dam of the Augustowska reservoir. For this purpose, the surface areas and conditions of use of the stream's sub-catchments were modified so that they would reflect the conditions of July 2001 as accurately as possible. Additionally, all retention reservoirs were removed from the model because they were built after 2001. The input to the model was the precipitation time distribution recorded during the flood. Unfortunately, at that time, the observation network was limited to the outposts of Port Północny and Rembiechowo, as well as the station of the Gdańsk University of Technology, which means that the spatial distribution of precipitation is largely an estimate. The mathematical model thus developed generated the value of the flow in the closing cross-section, reaching 


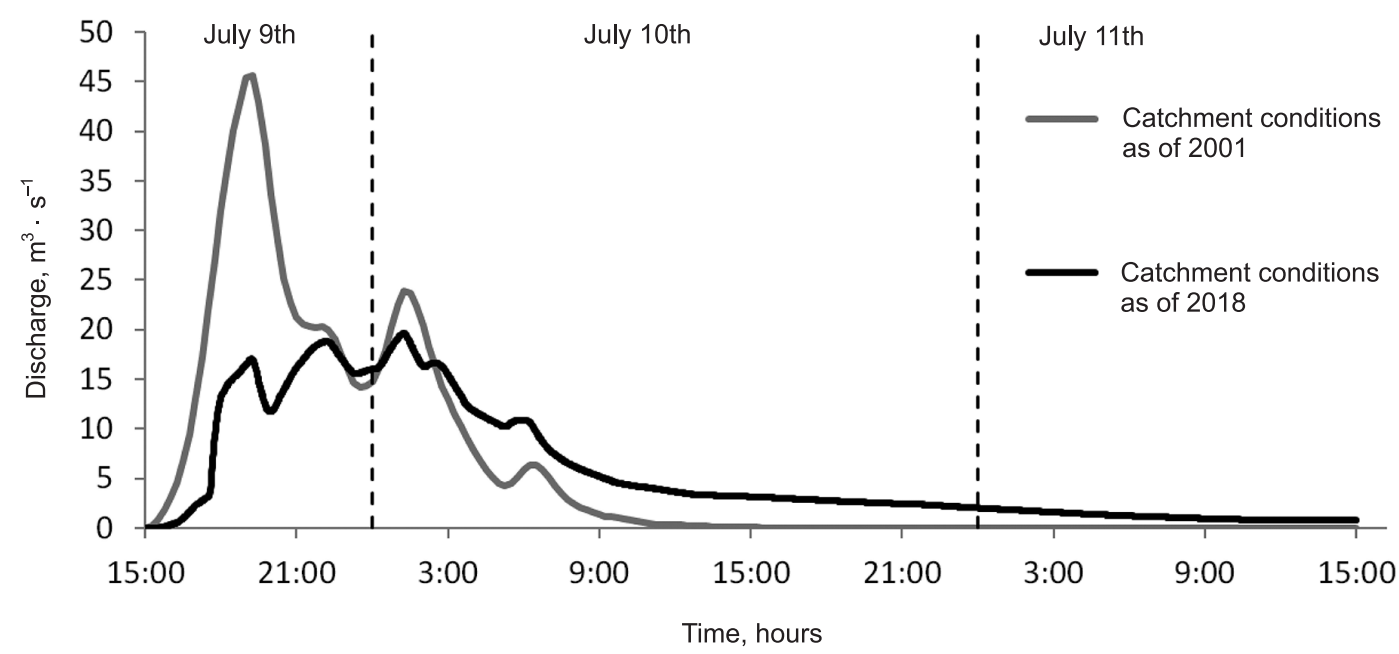

Fig. 6. Calculated discharge at Augustowska reservoir's outlet cross section for July 2001 storm

the maximum of $45.6 \mathrm{~m}^{3} \cdot \mathrm{s}^{-1}$. It should be emphasized that the model did not cover the whole of the Oruński Stream catchment, and therefore the inflow to the Radunia Canal could actually be even larger.

Next, a simulation was carried out in order to check the operational effectiveness of the flood protection system of the Potok Oruński in its current state, that is, considering all retention reservoirs except the $\mathrm{Z} 3$ reservoir, which is at the design stage. By assigning a distribution of rainfall identical to the situation in 2001, a significant reduction of the flood surge was achieved. In the cross section of the Augustowska reservoir, the maximum flow reached $18.8 \mathrm{~m}^{3} / \mathrm{s}$, which constitutes a nearly $60 \%$ reduction in the flow compared to the conditions prior to installing the retention reservoir system. It is worth noting that the designated maximum flow on the Augustowska reservoir's spillway structure exceeds the assumed capacity of the structure in question. This means that for the proper functioning of the system, it is necessary to use an emergency spillway on this structure, which shall protect it in the case of extreme situations.

\section{CONCLUSIONS}

The city of Gdańsk is threatened by flash floods due to its geographical location. There are many possibilities to counteract the effects of these floods, above all, the methods of reservoir retention, field retention, street retention, backyard retention, as well as urban greenery (Gajewski 2018). All the above technical measures are used to increase the retention capacity of urban areas and they should be treated as equivalent and complementary methods, whose strength lies in the sum total of their collective impact.

Having said that, reservoir retention is the most effective method of flood prevention. Due to the fact that urban zones rarely have large free areas of land, the developed reservoirs are often small. In the Potok Oruński catchment, all the built reservoirs fall within the category of the so-called "small-scale retention", because their volume does not exceed 5 million $\mathrm{m}^{3}$. Despite the small capacity of flood storage, the retention reservoirs located in the city of Gdańsk have repeatedly proven their extremely important contribution to reducing the impact of the flood wave. The Gdańsk flood defence system is constantly being supplemented with new solutions, among which we should mention the new Z3 reservoir described in this article, as well as the $\mathrm{K} 1$ and $\mathrm{K} 2$ reservoirs on the Kowalski Stream along with the system of water transfer from this stream to the Świętokrzyska 2 reservoir (see: Z2 in Figure 1). The calculations carried out in the operational conditions of the entire flood protection system, taking into account the prospective development of the catchment in accordance with the spatial development plans, confirmed the safe conduct of rainwater with a probability of exceedance of $1 \%$ and $0.5 \%$. A prerequisite for en- 
Kolerski, T., Kalinowska, D. (2019). Mathematical modeling of flood management system in the city of Gdańsk, Oruński stream case study. Acta Sci. Pol., Formatio Circumiectus, 18(1), 63-74. DOI: http://dx.doi.org/10.15576/ASP.FC/2019.18.1.63

suring the flood safety of the Potok Oruński catchment is maintaining the surface retention capacity of areas that have been and will be subjected to urbanization. It is anticipated that such activities will only apply to municipal investment projects and to high-density built development, where the city will be able to require designers to undertake all necessary rainwater management measures as part of these ventures.

In order to confirm the thesis about the effectiveness of the flood protection system on the Potok Oruńs$\mathrm{ki}$, a simulation of the July 2001 flood was carried out. The implementation of the mathematical model to historical conditions showed $45 \mathrm{~m}^{3} / \mathrm{s}$ flow in the closing cross section. When considering the entire flood protection system, the catchment was able to retain much more water from historical precipitation, whereas the inflow to the Radunia Canal decreased by almost $60 \%$.

In the paper, we indicate high importance of mathematical models that can support the decision-making process when planning and designing a flood protection system. Additionally, thanks to the developed precipitation and water level monitoring system, we were able to calibrate the model, which significantly validated the obtained results of numerical simulations. The high consistency of the actual observations with the results computed from the mathematical model indicates that the calculation formulas were adopted correctly, both in terms of hydrological losses and the time of concentration (lag time).

\section{REFERENCES}

Bogdanowicz, E., Stachý, J. (1998). Maksymalne opady deszczu w Polsce: charakterystyki projektowe. Warszawa: Instytut Meteorologii i Gospodarki Wodnej.

Dysarz, T. (2018). Application of Python Scripting Techniques for Control and Automation of HEC-RAS Simulations. Water, 10(10), 1382.

Edel, R. (2002). Odwodnienie dróg. Warszawa: Wydawnictwa Komunikacji i Łączności.

Egiazarova, D., Kordzakhia, M., Wałęga, A., Drożdżal, E., Milczarek, M., Radecka, A. (2017). Application of Polish experience in the implementation of the flood directive in georgia - hydrological calculations. Acta Sci. Pol., Formatio Circumiectus, 16(3), 89-110.

Gajewski, R. (2018). Miasto - woda - zmiany klimatu. Rozwiązanie gdańskie, Książka abstraktów XXXVII Ogólnopolskiej Szkoły Hydrauliki.
Gąsiorowski, D. and Szymkiewicz, R. (2007). Mass and momentum conservation in the simplified flood routing models. Journal of Hydrology, 346(1-2), 51-58.

Gąsiorowski, D., Artichowicz, W. (2016). Modelowanie przepływów nieustalonych na terenach zalewowych z wykorzystaniem dwuwymiarowego równania fali dyfuzyjnej. Acta. Sci. Pol., Formatio Circumiectus, 15(4), 193-207.

Heathcote, I.W. (2009). Integrated watershed management: principles and practice. Noboken: John Wiley \& Sons.

Kolerski, T. (2014). Modeling of ice phenomena in the mouth of the Vistula River, Acta Geophysica, 62(4), 893-914

Kolerski, T., Kowalik, M. (2014). Wyznaczanie odpływu ze zlewni niekontrolowanych Kanału Raduni podczas powodzi w 2001 r., Inżynieria Morska i Geotechnika 02, 35(1) 3-10

Kolerski, T., Szawurska, D. (2017). Flood management in urban basins of the city of Gdańsk, Proceedings of the 15th International Symposium on Water Management and Hydraulics Engineering, 84 - 92

Majewski, W., Jasińska, E., Kolerski, T., Olszewski T. (2006). Zagrożenia powodziowe Gdańska oraz proponowane zabezpieczenia $\mathrm{w}$ świetle powodzi w lipcu 2001 r., Gospodarka Wodna 2006(7) 260-267

Maniak, U. (1988). Hydrologie und Wasserwirtschaft, Niederschlag-Abfluß-Modelle für Hochwasserabläufe. Berlin Heidelberg: Springer, 282-380

Mays, L. W. (2010). Water Resources Engineering. Hoboken: John Wiley \& Sons.

McCuen, R.H., Johnson, P.A., Ragan, R.M. (2002). Highway Hydrology: Hydraulic design series number 2, National Highway Institute, Federal Highway Administration. FHWA-NHI-02-001, p 424.

Olechnowicz, B., Weinerowska-Bords, K. (2014). Impact of Urbanization on Stormwater Runoff from a Small Urban Catchment: Gdańsk Małomiejska Basin Case Study. Archives of Hydro-Engineering and Environmental Mechanics, 61(3-4), 141-162.

Pietruszyński, Ł., Cieśliński, R. (2016). Wpływ opadu atmosferycznego na stan jakościowy rzeki miejskiej na przykładzie Potoku Oruńskiego. Inżynieria Ekologiczna, (49), 151-161.

Rozporządzenie Ministra Środowiska z dnia 20 kwietnia 2007 r. w sprawie warunków technicznych jakim powinny odpowiadać budowle hydrotechniczne i ich usytuowanie. Dz. U. z 2007 r. Nr 86, Poz. 579

Sawicki, J.M. Kondziela, A. (2002). Aktualizacja hydraulicznych parametrów sieci deszczowych. Gaz, Woda i Technika Sanitarna, (6), 208-215. 
Kolerski, T., Kalinowska, D. (2019). Mathematical modeling of flood management system in the city of Gdańsk, Oruński stream case study. Acta Sci. Pol., Formatio Circumiectus, 18(1), 63-74. DOI: http://dx.doi.org/10.15576/ASP.FC/2019.18.1.63

Szpakowski, W. Szydłowski, M. (2018). Evaluating the Catastrophic Rainfall of 14 July 2016 in the Catchment Basin of the Urbanized Strzyża Stream in Gdańsk, Poland. Polish Journal of Environmental Studies, 27(2).

Szydłowski, M., Mikos-Studnicka, P., Zima, P., Weinerowska-Bords, K., Hakiel, J., Szawurska, D. (2015). Stormwater and snowmelt runoff storage control and flash flood hazard forecasting in the urbanized coastal basin. In 14th International Symposium Water Management and Hydraulic Engineering.

Szydłowski, M., Mikos-Studnicka, P. (2015).Wpływ jakości danych hydrologicznych na oszacowanie odpływu ze zlewni miejskiej na przykładzie potoku Strzyża w Gdańsku. Inżynieria Ekologiczna, (44), 139-153.

Szydłowski M., Zima P. (2013). Zastosowanie modelu opad-odpływ do oszacowania spływu wód opadowych z górnej części zlewni potoku Strzyża w Gdańsku, po- przedzającego awarię zbiornika Nowiec II. B. Więzik (ed.) Problemy obliczania przepływów ekstremalnych w zlewniach kontrolowanych i niekontrolowanych. Tom II. Warszawa: Komitet Gospodarki Wodnej PAN, $83-100$.

Ustawa z dnia 20 lipca 2017 r. - Prawo wodne; Dz.U. 2017 poz. 1566 z późniejszymi zmianami

Wałega, A. (2013). Application of HEC-HMS programme for the reconstruction of a flood event in an uncontrolled basin. Journal of Water and Land Development, 18(9), 13-20.

Weinerowska, K. (2010). Wpływ uproszczeń na obliczenie spływu deszczowego w zlewni zurbanizowanej. Gdańsk: Wydawnictwo Politechniki Gdańskiej.

Węglarczyk, S. (2010). Statystyka w inżynierii środowiska: podręcznik dla studentów szkół wyższych. Kraków : Wydawnictwo Politechniki Krakowskiej.

\section{MODELOWANIE MATEMATYCZNE SYSTEMU OCHRONY PRZECIWPOWODZIOWEJ MIASTA GDAŃSKA, NA PRZYKŁADZIE ZLEWNI POTOKU ORUŃSKIEGO}

\section{ABSTRAKT}

\section{Cel pracy}

Celem pracy jest potwierdzenie efektywności pracy systemu zbiorników retencyjnych na redukcję fali wezbraniowej generowanej na obszarze małej w zlewni zurbanizowanej. Dodatkowo, w artykule zweryfikowano procedurę obliczeniową dla modelu typu opad-odpływ, na podstawie danych uzyskanych z sytemu monitoringu.

\section{Materiał i metody}

W pracy zaimplementowano model matematyczny o parametrach skupionych na zlewni Potoku Oruńskiego. Uwzględniono transformację fali wezbraniowej w korycie potoku według metody fali kinematycznej. Analizę podziału zlewni przeprowadzono na podstawie map topograficznych i zdjęć satelitarnych. Do ustalenia wskaźników CN wykorzystano mapy glebowe, Plany Zagospodarowania Przestrzennego miasta Gdańsk i inne dostępne materiały. Na tej podstawie wyznaczono granice zlewni, podzielone na zlewnie cząstkowe o określonych parametrach takich jak m.in.: powierzchnia, spadek, długość drogi spływu, czas koncentracji, możliwości retencyjne. Model został wykalibrowany na podstawie epizodu opadowego z kwietnia 2018 r. wykorzystując dane z monitoringu. Następnie zaadoptowano wykalibrowany model do sytuacji historycznej powodzi z roku 2001 r. przy zmienionym użytkowaniu zlewni. Przeprowadzono również analizę reakcji zlewni na sytuacje teoretyczne wystąpienia opadów o prawdopodobieństwie przewyższenia 1 i $0,5 \%$ Symulacje wykonano dla deszczów o różnym czasie trwania: wybierając jako opad miarodajny wariant najniekorzystniejszy (wywołujący największy hydrogram odpływu). W analizach uwzględniono zarówno stan istniejący zgodny ze stanem użytkowania zlewni na rok 2001 i rok 2016 oraz planowane użytkowanie terenu zgodne z planami zagospodarowania przestrzennego miasta Gdańska.

\section{Wyniki i wnioski}

Implementacja modelu matematycznego do warunków historycznych wykazała przepływ w przekroju zamykającym model matematyczny na poziomie $45 \mathrm{~m} 3 / \mathrm{s}$. Po uwzględnieniu całego systemu ochrony przeciwpowodziowej zlewnia była w stanie retencjonować znacznie więcej wody z historycznego opadu, a dopływ do kanału Raduni zmniejszył się o niemal 60\%.

Słowa kluczowe: modelowanie matematyczne, HEC-HMS, Potok Oruński 